\title{
International diversification and economic development in a regional context: $A$ dynamic capabilities approach
}

Abel Duarte Alonso, Ph.D. (Corresponding author), Senior Lecturer, School of Management, Curtin Business School, Curtin University, BL 402, Kent St., Bentley, 6102 WA, Australia. Email: a.alonso@ curtin.edu.au. Research interests include micro, small and medium enterprises, family enterprises, innovation, wine entrepreneurship, tourism, hospitality, and community development.

Seng Kok, Ph.D., Senior Lecturer, Liverpool Business School, Liverpool John Moores University, Redmonds Building Brownlow Hill, Liverpool, L3 5UG. Email:

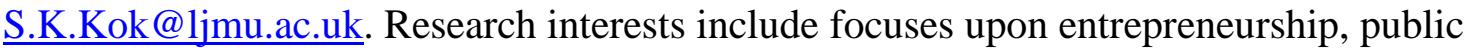
sector management and higher education management.

Michelle O'Shea, Ph.D., Lecturer, School of Business, Western Sydney University, Locked Bag 1797, Penrith South DC, NSW 2571, Australia. Email:

m.oshea@westernsydney.edu.au. Research interests include entrepreneurhsip, sport management and community development.

\begin{abstract}
This exploratory study proposes a theoretical framework grounded on the dynamic capabilities approach to facilitate understanding of the role of managerial resources and dynamic capabilities in international diversification (ID) initiatives in a changing business environment in the context of Western Australia (WA). Data were gathered through interviews with representatives of this state's chambers of commerce, government agencies and town halls. While the identified ID strategies will not replace the state's ubiquitous mining industry, these were nevertheless perceived as significant contributors to its future economic performance. The strategies primarily emphasised the potential and value of further developing tourism, international education, innovative and technological resources, and premium agricultural products. The proposed framework provides an interpretative and guiding tool, which highlights the strategic importance of a region's alternative resources as contributors of its diversification, economic development, and competitive advantage. In addition, the study will discuss various implications from the findings and identify future research strands.
\end{abstract}

Keywords: Dynamic capabilities, country/region attractiveness, economic potential, Western Australia.

\section{Introduction}

The extraction of natural resources underpins the economy of many communities (Chapman et al. 2015). In the case of Australia, the socioeconomic importance of mining has been discussed in contemporary research (e.g., Perry and Rowe 2015; Tonts et al. 2013). Mirroring the success of other Australian regions where mining is predominant, for over a decade, the state of Western Australia (WA) has experienced sustained economic growth, which has been principally driven by supply and demand factors, notably, the consistent growth of China's economy (Chapman et al. 2015). 
Indeed, in 2016, exports to China, particularly iron ore (Government of Western Australia 2016) represented AU\$51.8 billion, or 46.9 percent of WA's total export share of goods trade (DFAT 2017).

Furthermore, in 2016, iron ore represented 83.8 percent of WA's exports; these exports increased from 127 million tonnes to 652 million tonnes within a decade (20062016), or nearly 18 percent per year (Australian Government 2017a). Consequently, the state's dependence on its natural resources and allied industry is significant (Lawrie et al. 2011). Albeit continuous growth, the changing nature of the business environment has affected WA's economy. For instance, in 2015 two factors contributed to the beginning of the end for WA's mining boom, notably, the slowdown of China's economy, and the fall of iron ore price (Lenzen et al. 2017). In addition, while iron ore prices slightly rebounded in recent times (Thornhill 2017), the mining industry has experienced many job losses, particularly between 2013 and 2015 (Wahlquist 2017). Furthermore, global competition, particularly in iron ore production, has increased, with the emergence of new exporting nations, including Brazil (Weiss and Greenwood 2015).

In view of the economic dependence on the predominant mining industry, and potential boom and bust cycles (Petkova et al. 2009), the international diversification (ID) of WA's economy could help cushion the effects of downturn cycles. The academic literature and industry reports underscore the significance of diversification strategies, not only as a tool for economic growth (Al-Marhubi 2000), but also in improving well-being (Lawrie et al. 2011), and in lessening dependence on predominant industries (Goldstein et al. 2006). Within a firm context, diversification has been conceptualised as the degree "to which firms classified in one industry produce goods classified in another" (Kamien and Schwartz 1975, p. 13). ID, on the other hand, refers to "expansion across the borders of global regions and countries into different geographic locations and markets" (Hitt et al. 1997, p. 767).

Several emerging industries illustrate WA's potential to diversify in a changing business environment. Indeed, agriculture, together with fisheries, food, forestry, and fibre accounted for AU\$8.5 billion or 7\% of WA's exports in 2016-2017 (Government of Western Australia 2017). In 2016, China's investments in WA totalled AU\$1.38 billion, with the mining industry being the recipient of 54 percent, or AU\$745 million (Government of Western Australia 2016), while agribusiness was China's second investment, with AU\$333 million (Government of Western Australia 2016).

Education represents another area of future business growth. In 2015, 50,480 international students enrolled in WA's institutions, or 7.8 percent of Australia's total international student intake; the value of the international education sector was AU\$1.39 billion (WAPETIA 2016). China was WA's most significant market for international students (higher education), with 6,990 (13.9\%), followed by India $(6,140,12.2 \%)$ and Malaysia (3,550, 7.0\%) (WAPETIA 2016). However, the case of Brazil, with 2,630 students (5.2\%) (WAPETIA 2016) also suggests opportunities for exploring nontraditional markets.

The tourism industry is further illustrative of WA's ID potential. In 2018, WA received 963,380 international visitors, a 2.1 percent increase from the previous period (Tourism WA 2019). Also in 2018, international visitors spent AU\$2.2 billion; while the United Kingdom, Malaysia, Singapore, and the United States were the main visiting groups, China was the group spending the most, or AU\$259 million (Tourism WA 2019).

Despite the significance of diversification in lessening the impact of a predominant industry, recent academic studies have overlooked this dimension, including in WA. 
New empirical data, particularly gathered from trade and economic development experts' experiences and interpretations, could contribute to new knowledge among different industry, government, or international stakeholders of the state's potential. In turn, this knowledge could be operationalised through new investment opportunities, and overall, in enhancing WA's image internationally.

Against this background, the present study will first make a contribution to the literature of ID and entrepreneurship, gathering empirical evidence. Moreover, the study will focus on diversification opportunities for WA's economy, potentially decreasing its dependence on the natural-resource industry. A group of expert informants, predominantly local chambers of commerce and town hall representatives in WA were interviewed. The following overarching research questions are explored:

- How could ID contribute to WA's future competitiveness in a changing business environment?

- Specifically, what resources could enable WA's ID, thus, complementing its natural resource-based dependent economy?

Second, the study will also make a theoretical contribution, by proposing a framework to facilitate understanding of managerial resources and dynamic capabilities in diversification in a changing business environment. The links between WA's ID strategies, its resources, and the changing business environment suggest the value of the dynamic capabilities approach (DCA) (Eisenhardt and Martin 2000; Teece et al. 1997) to illuminate the research. Thus, an additional research questions is proposed:

- To what extent does the DCA contribute to a better understanding of the associations between managerial resources, dynamic capabilities and ID strategies?

\section{Literature Review}

\subsection{Dynamic capabilities and the DCA}

According to Teece et al. (1997), acceptable definitions are necessary to facilitate intellectual dialogue and theory development. These authors conceptualise the term 'dynamic' as "the capacity to renew competences" (p. 515), and attain congruence with the changing, and increasingly competitive business environment (Leih and Teece 2016). Moreover, renewing competences, together with attaining congruence, are associated with innovative responses, for instance, when the composition of future markets or competition are difficult to ascertain, or when technology is evolving rapidly (Teece et al. 1997). Furthermore, the term 'capabilities' underscores the fundamental role played by strategic management, in appropriately integrating, reconfiguring, or adapting external as well as internal resources, functional competences, and skills to enable better response to the demands of changing environments (Teece et al. 1997). Dynamic capabilities (DCs) are defined as firms' ability to build, reconfigure, and integrate external and internal competences in response to rapidly changing environments" (Teece et al. 1997, p. 516). They consist of specific and identifiable routines, though some integrate resources (Eisenhardt and Martin 2000).

The DCA is an extension of the resource-based view (RBV) of the firm framework (Ambrosini and Bowman 2009). This framework emphasises the strategic importance of heterogeneity and immobility, and emphasises that firms' competitive and sustained competitive advantage is based on valuable, rare, imperfect imitable and non-substitutable managerial resources (Barney et al. 2001), also known as the VRIN framework (Teece 2014). Drawing from Daft's (1983) contribution, Barney (1991) identified firms' managerial resources in terms of capabilities, assets, knowledge, information, organisational processes or attributes that enable firms to implement strategies to improve their effectiveness or efficiency. 
In referring to Leonard-Barton's (1992) work, Teece et al. (1997) argued that DCs reflect organisations' ability to be innovative and identify new ways of attaining a competitive advantage, given market positions and path dependencies. DCs provide firms with the capacity to firmly modify, extend, or create a resource base; in essence, they are about change (Maritan 2007). DCs determine the degree and speed at which firms' specific resources are aligned and realigned in order to match the opportunities and demands of business environments and help generate sustained positive returns (Teece 2012). In addition, DCs fall into the following clusters of adjustments and activities that firms must perform skilfully if they are to thrive in changing environments:

Sensing: Identifying and assessing opportunities.

Seizing: Mobilising resources to exploit opportunities, thereby capturing value.

Transforming: Continued renewal (Teece 2012).

Related to these clusters, the DCA attempts to assess "the sources of wealth creation and capture by firms" (Teece et al. 1997, p. 509), thus, emphasising the significance of dynamic processes to build capabilities and gain competitive advantage (Weerawardena et al. 2007). In this context, the DCA provides a coherent and evolutionary ideology that helps elucidate "how firms develop competitive advantage, and maintain it over time" (Augier and Teece 2007, p. 179). The approach also emphasises internal processes firms employ, how they are deployed and evolve (Teece et al. 1997). Aligned with the RBV, the DCA seeks to direct managers to create difficult-to-imitate and distinctive advantages (Teece et al. 1997). In order to achieve this state, the acquisition of strategic knowledge plays a key role. Indeed, building DCs comprises processes that, notably, are knowledge-based and crucial in the creation of knowledge, as well as in its configuration and integration (Weerawardena et al., 2007).

Teece's (2014) more recent contribution to the DCA also offers significant theoretical insights, notably, in the form of a logical structure of the framework. This framework is based on the premise that, instead of operating alone, DCs need effective strategizing in order to generate competitive advantage (Teece 2014). The framework theorises that organisational capabilities are drivers of enterprise performance, are supported and shaped by VRIN resources. In addition, organisational capabilities need to integrate strong DCs, namely, with sound strategies in order to create strong firm performance (Teece 2014). Overall, Teece's (2014) framework postulates that sound strategy, strong DCs and VRIN resources are necessary for the long-run of the enterprise's financial success.

A review of the academic literature reveals that empirical research incorporating the DCA to examine a country's or region's ID is scant. Instead, the adoption of the DCA to explain firm internationalisation through diversification is well-documented. For example, Evers (2011) studied new international ventures involved in the traditionally low technology-based seafood processing industry. Evers's (2011) research revealed the importance of product diversification strategies to underscore firms' capability to renew themselves and adapt; these strategies were vital for firms to attain sustainable competitive advantage in a significantly competitive seafood industry. Moreover, product diversification enabled firms to enter and expand into new markets, and add value to their products (Evers 2011). Furthermore, Villar et al. (2014) examined non-high technology exporting firms and found that DCs were at the core of firms' performance in export intensity, particularly as these firms were operating in the globalised manufacturing industry. This finding strongly illustrates the development of a competitive advantage through knowledge management,

Another study, which examined a small global factory (Eriksson et al. 2014) uncovered other insightful elements of DCs. Indeed, cognitive capabilities, such as entrepreneurial orientation, displaying a global mindset and cultural awareness emerged as precursors to recognising and exploiting international opportunities (Eriksson et al. 2014). Thus, cognitive capabilities, which rest on absorptive capacity, managerial capabilities and organisational 
flexibility, can contribute to providing direction to the firm internationally (Eriksson et al. 2014).

\subsection{Proposed theoretical framework}

Theory building has been conceived as a cycle or process by which theoretical representations are tested, refined, or generated (Gioa and Pitre 1990). Wacker (1998) underscores the importance of theory building, in providing "a framework for analysis, [which] facilitates the efficient development of the field, and is needed for the applicability to practical real world problems" (p. 361). Based on these premises, the present study proposes a theoretical framework (Figure 1), whose foundation rests on the DCA.

As other parts of the world, WA has experienced significant changes in its business environment. As indicated previously, WA's exports to China, particularly iron ore, constantly increased over the last decade (Government of Western Australia 2016). Consequently, WA's economy has become more China-dependent, which suggests potential vulnerability in the case of a downturn of such a large trading partner, or, as Lenzen et al. (2017) explained, in case of falling global prices. This issue could become aggravated by increasing global competition in the iron ore industry (Weiss and Greenwood 2015). Furthermore, the China-Australia free trade agreement, which came into force at the end of 2015 (Australian Government 2017a) also illustrates a significant change and commitment, though it also implies Australia's preparedness to build new alliances, and exploit commercial opportunities. Importantly, strategic alliances are intrinsically related to DCs (Helfat and Peteraf 2009).

Figure 1 Here

Furthermore, the framework suggests the influence of managerial resources (VRIN) and DCs on dynamic processes, which are illustrated by WA's ID strategies, thus, highlighting the significance of the DCA. The notion of dynamic processes also aligns with earlier research (e.g., Augier and Teece 2008; Liu and Hsu 2011), which established links between diversification and DCs. Notably, Trendle and Shorney (2003) tested and confirmed an assumed relationship between a region's economic performance and a more diversified regional economy. In the context of WA, Tonts and Selwood (2003) studied the potential of sandalwood production as "a significant component of a wider regional diversification strategy" (p. 571), including by adding value to recent exports. These authors determined that success among companies involved in sandalwood production was based primarily on their strong focus on research and development, on identifying specialised market needs, and on their entrepreneurialism. Therefore, Tonts and Selwood's (2003) findings are associated with DCs, and with entrepreneurship, which George and Zahra (2002) define as the process and act by which regions, individuals, organisations or societies pursue or identify business opportunities to generate wealth. The associations between DCs and entrepreneurship have also been discussed in the contemporary academic literature (e.g., Arend 2014).

The framework also hypothesises that the role of strategic management (Teece et al. 1997), clusters of activities and adjustments (Teece 2012), knowledge acquisition and integration (Weerawardena et al. 2007), and entrepreneurship (George and Zahra, 2002) help identify various ID strategies. In the case of WA, some of these ID strategies (e.g., agriculture, education, tourism) that are knowledge-based, difficult to imitate and that represent distinctive advantages (Teece et al. 1997), have been implemented and are already contributing to the state's economy. Ultimately, these distinctive advantages have a direct effect on the state's sustained competitive advantage, as stand-alone activities, as well as complementing its predominant mining industry. 


\section{Methodology}

In adopting the DCA as the theoretical paradigm, this empirical and qualitative study examines the significance of ID for a state's economy in light of a changing business environment. Consequently, the study's unit of analysis emphasises the importance of ID for the competitiveness of a region, particularly where one predominant industry (mining) exists. The study also proposes a framework to facilitate understanding of the interplay between a state's resources, DCs and their implications for ID in a changing business environment (Figure 1). In this study, the 'firm', which is often referred to in the DCA literature, will be illustrated by the state of WA.

In accord with contemporary research on firm diversification (e.g., Cieślik et al. 2012; La Rocca et al., 2009), the study considers one of the two approaches of reasoning, notably, inductive reasoning. This approach entails the usage of "simple models to fill the gaps in our understanding" (Arthur 1994, p. 407). Moreover, inductive reasoning represents a progression, "from particulars (observations, measurements, data) to generalities (governing rules, laws, theories)..." (p. 677). Thus, inductive reasoning is suggested to be a theory building process (Hyde 2000), whereby the analysis of qualitative (raw) data is expected to be guided by certain evaluation aims (Thomas 2006).

Hood (2007) explains that, typically, qualitative research employs "some form of purposeful sampling" (p. 157), a method which consists of identifying and selecting information rich cases that are associated with "the phenomenon of interest" (Palinkas et al. 2015, p. 533). Studying information rich cases will then illuminate the questions being addressed, and allow researchers to learn extensively about issues of vital importance to the aims of the inquiry (Patton 2002). The present study adopts one type of purposive sampling, namely, an 'a priori' purposive sampling. In this methodology, the researcher decides the situations or categories of participants to sample, and the number of the participants to be included in each category (Hood 2007).

In order to ascertain WA's ID strategies and initiatives, the involvement of individuals who are knowledgeable of the state's trade and economic development was considered. This decision is aligned with the principle of the selection of information rich cases (Palinkas et al. 2015; Patton 2002). To this end, 25 organisations that included chambers of commerce, government agencies and town halls/shires were identified. Apart from four organisations located between 300-800 kilometres from the city of Perth, WA, all were mainly located in and around its periphery, to maximum of 100 kilometres.

Between June and August of 2015, eight chambers of commerce, 10 town halls/shires, 6 government agencies, and a regional ports agency were contacted by email communication. The message sent to the attention of the chief executive officer, general manager, coordinator or director, provided a synopsis of the research objectives, and asked the recipients to participate. From the 25 contacted organisations, representatives of 14 positively replied. Within these organisations, 15 individuals expressed their interest to participate; in one case, two individuals from the same organisation agreed to be interviewed.

Table 1 shows the composition of participants and their organisations. In 11 cases, the research team travelled to conduct face-to-face interviews, while in four other cases, due to the geographic distance, interviews were conducted over the telephone. Based on participants' availability, the interviews were conducted between August of 2015 and February 2016; on average, the length of the interviews was 45 minutes. The interview data were complemented by industry reports, information on the organisations' websites, and also by subsequent email communication with various participants. The interview protocol included questions about participants' professional background and experience in their role. Subsequently, the interview sought to examine the following key questions: 
- Based on your knowledge and expertise, in what specific ways (i.e. industries) could WA exploit ID?

- Overall, how could ID contribute to WA's future competitiveness?

These broad questions were designed based on contemporary regional and ID research (e.g., Mayer et al. 2015; Tonts and Selwood 2003; Trendle and Shorney 2003). The questions allowed participants to reflect on ongoing as well as future projects, initiatives, and plans to help diversify the state's economy, while promoting competitiveness.

After gathering the data, qualitative content analysis was undertaken. This research method entails the interpretation of text data, and is grounded on a systematic classification process of recognising and classifying themes and/or patterns (Hsieh and Shannon 2005). To assist in this process, NVivo (version 11), a computer assisted qualitative data analysis software (Welsh 2002), was employed. As shown in Table 2, NVivo enabled the development and grouping of thematic nodes by word similarity, thus, complementing the numerical data.

Despite numerous academic contributions on the subject, no agreed upon guideline exists on when to employ, how to report or identify data saturation (Walker 2012). This state occurs when no new themes or information are noticed in the data (Guest et al. 2006), when sufficient information has been gathered to replicate the research or "when further coding is no longer feasible" (Fusch and Ness 2015, p. 1408). An earlier study (Guest et al. 2006) noticed saturation within the initial 12 interviews, though some recurrent elements emerged after the sixth interview. However, another study (O'Reilly and Parker 2013) concludes that the number of interviewees is not the only determining factor for the adequacy of the sample; instead, it is "the appropriateness of the data" (p. 195). In the present study, no additional themes and patterns were noticed after the $15^{\text {th }}$ interview, suggesting saturation of research results.

\subsection{Demographic characteristics of participants}

As illustrated (Table 1), chambers of commerce and town halls/shires were the main organisations represented, while directors and coordinators comprised the main participant groups. On average, participants had six years of experience in their role, clearly highlighting their expertise and knowledge of trade, economic development and other themes.

Table 1 Here

In fact, nine different participants had previous industry background or experience in managerial roles, including in government and international trade. P1, for instance, had previously worked in the United Kingdom, New York, and Australia in the areas of international trade and in freight forwarding. P11 had worked in economic development in South Africa and New Zealand, while P13 had completed an eight-year government post in India as a foreign trade advisor.

\section{Results}

\subsection{ID in the context of WA}

Through the 15 in-depth interviews, and as Table 2 illustrates, participants' comments referred to as many as 11 forms of ID. More importantly, the comments underscore the importance of managerial resources and DCs, in that these ID avenues demonstrate the entrepreneurial and dynamic background of WA firms and their industry. First, the importance of international tourism was perceived as the state's main form of ID. This potential is not only aligned with recent international visitor figures (Tourism WA, 2019), but 
also with contemporary academic research. For instance, Rodger et al. (2015) highlighted opportunities in nature based tourism. Various views further illustrated opportunities for growth in international markets, exploiting the diversity of the state's tourism alternatives:

P5: I think certainly...tourism has started to change... [We are] starting to get a lot of international tourism here now. Previously we didn't get any - it was all just like day trippers. Now we're starting to get particularly a lot of people from Asia... we intend to grow our 'articultural' sector. Now part of that will be articultural tourism, Indigenous tourism... and we're identifying some opportunities right now.

P14: We have a variety of products down here and the opportunity to showcase all the products that the region has to offer... UK is number one in the [WA] international market. New Zealand is number two and Singapore is close. We're looking for the Chinese market that may be... a bit more affluent... they have a bit more appreciation of the quality of product that we offer down here when it comes to the food and the wine.

P5's comment is partly supported in tourism research (Pforr et al. 2014) that identified the potential for tourism to extend beyond hot spots or major centres, and include the exploration of the state's more remote areas. The importance of the Singaporean tourist market, as well as that of other countries, was also underlined by $\mathrm{P} 4$, who stressed the significance of forging relationships to build an image of WA among international travellers: "we've worked with Singapore Airlines as well. We've done a Swan Valley documentary and that'll be on all of their flights for six months, and then we can take that out to other airlines to use as well."

The academic literature also identifies various hurdles preventing the further development of tourism in WA. Pham et al. (2015) explained that, while WA's mining boom has been an undisputable and significant source of revenues, its effects on the state's tourism have been largely negative. They used the term 'the Dutch Disease' to refer to the impacts from the success of a strong, predominant industry on other one, less financially significant sectors. More precisely, the strengthening Australian dollar at the time of the country's mining boom has had direct consequences, particularly in shifting travel preferences to other international destinations (Pham et al. 2015).

Education was the second most discussed key ID strategy for WA's economy. This finding complements industry information (WAPETIA 2016) and academic research (e.g., Basha et al. 2015) that emphasises the importance of Australia's international education as a revenue source. To exploit education-based opportunities, and in line with P4's comment, P1 referred to the strategic importance of building alliances internationally and tap into future opportunities: "There's still [an] opportunity, definitely. I think that's something the universities need to look at, partnerships... Every university of any size at the moment is looking at that, having a partnership as an opportunity..."

\section{Table 2 Here}

As with tourism, participants discussed various challenges in creating a sustainable international education strategy. P1, who had lived in various English speaking nations and worked extensively in international trade, explained that, again, the high value of the Australian dollar could be a hindrance when competing with other countries offering similar services. However, these issues could be addressed, for instance, by having a presence internationally. Such was the opportunity P13 identified, notably, in exporting education to India: "if you look at a market like India where the Prime Minister has a fairly ambitious 
plan to upskill something like half a billion people by 2020... There will be a fairly large group of people that will be looking to get skills in a whole range of skills areas... and again Australia and WA certainly have history and experience in being able to deliver practical training modules..."

Third, the value of existing innovative activities and technological developments was alluded to in the context of regional and ID. For example, P13 referred to innovation and technology in the mining industry as a source of training skills that could be drawn on and make improvements in other emerging industries: “...it's important to look at developing and supporting industries of opportunity that really build on what has positioned WA in the international business of today... we've got some wonderful examples of innovation and cutting-edge technology and foresight that we can apply in other areas." P13 also highlighted the opportunities to position WA internationally, particularly "as best practice and in the way that we manage..."

P5 explained ongoing plans to build a large-scale industrial area outside Perth that would include high technology in green- and glass houses to produce high-intensity farming, and warehousing to add value to food production: "We've identified that we have the potential to become the food manufacturing hub of WA and that has massive potential for us here." Also concerning food production, P7 identified specific ways in which innovation and technology were playing a part, mentioning local farming enterprises that embraced energy efficient initiatives (e.g., solar energy), automated processes, or modern pest control and pollination techniques. These initiatives were complemented and extended in subsequent stages of the supply chain, including in cargo transportation. Moreover, P8 and P15 reflected on the modernisation of the region's port facilities, with new adopted technologies that allowed faster, safer, and more dynamic cargo operations, with clear implications for efficiencies in goods shipping exports/imports.

Innovation and technology also emerged in the context of the cultural/creative industries, which, as with other industries, have been affected by globalisation, or influenced by new technologies (Bennett 2012). Indeed, P12 reflected on the state's attributes, including its geographic isolation, and human resources, particularly skilled professionals, to position WA and take advantage of future commercial opportunities: "We're working more in the start-up, creative, innovation space where we're looking at the film industry, music licencing, digital communications and web technology... we're looking at isolation as a competitive advantage, not disadvantage... Some of the world's best photographers, videographers live within this region."

According to Brabazon (2012), given the importance of mining to WA's financial stability, until recently, the capacity, political will or desire to build a new economy has been absent. Furthermore, because of WA's strengthening commercial relationship with China, and therefore the continued predominance of mining, "the potential of creative industries... is deferred, deflected and denied" (Brabazon 2012, p. 173). However, P12's comment suggests an entrepreneurial drive among WA firms, and that creative and other industries have a space and a role to play in WA's future economic ID and development.

Fourth, and as emphasised in recent reports (DPIRD 2017; Government of Western Australia 2017), agriculture was also perceived as a valuable ID alternative. In 2015-2016, WA's agriculture was the second major exporting industry, with a value of AU\$ 7.64 billion (DPIRD 2017). As much as 80 percent of the state's agricultural production is exported, and 70 percent is destined to regional markets, particularly China, Indonesia and Vietnam (DPIRD 2017). P2 underlined the rising awareness among demanding international markets of the state's agricultural products: "if you go outside of Perth... there are large fields of carrots being grown... and the primary market is United Arab Emirates, and they [farming 
company] sell tons and tons of carrots. The reason is... the quality of the product, the perceived quality of the food coming from Western Australia."

Thus, and as a recent report (Department of Agriculture and Food, 2017) suggests, focusing on high-quality exports will help position WA's agricultural sector internationally. Moreover, while the prospects for the state to become a major global food supplier are very limited (P13): "We will never be able to feed the world and that's not the intent", agriculture will play an increasingly vital role in ID efforts:

P1: We've got a lot of foreign delegations coming into the state. They used to want to talk about mining, now they want to talk about agriculture only... So we're looking at actually promoting agriculture overseas and attracting investors.

P12: ...the trend will be to attract the agriculture projects and nature agricultural projects, and I think that's something to be developed over the next few years...

\section{Discussion}

\subsection{The findings and the proposed theoretical framework}

The proposed framework, which is based on the DCA, provides a lens identifying the associations between managerial resources, DCs, and competitive advantage in the context of a region's ID initiatives. Overall, the framework illustrates the importance of experts' knowledge and expertise, notably in identifying current and future opportunities for a region to diversify. These experts recognise and understand the changing environment, both domestically and internationally, in which the region's firms and industries operate. For instance, the mining industry, which is by far WA's most dominant industry, has gone through boom and bust cycles (Petkova et al. 2009). Furthermore, while there is current demand from large emerging markets such as China, growing competition and price fluctuations, particularly in iron ore (Lenzen et al. 2017) suggest the growing need, and also the potential, to diversify further.

The above notions are aligned with the DCA and related processes, particularly in the assessment of sources of wealth capture and creation (Teece et al. 1997). Such assessment is again based on the perceptions of experts holding strategic positions in WA's trade and commerce environment. The role of these experts, as well as that of government and industry stakeholders, becomes essential in identifying ID strategies based on managerial resources and DCs. Concerning the DCA, such a role is operationalised in various ways, including by sensing, seizing and transforming (Teece 2012).

Sensing became apparent in participants' experiences and interpretations of leveraging opportunities and diversify WA's economy in the process. Seizing was demonstrated through the valuable resources (human knowledge and expertise), organisational (building alliances and contacts internationally), strategic/financial (e.g., airport, port, road infrastructure; promotion of WA internationally). Moreover, the comments by P1 and P5, who underscored the importance of alliances in building international partnerships and therefore seeking to exploit opportunities, align with the literature (Helfat and Peteraf 2009), which identifies the associations between DCs and alliances. Finally, the transforming notion can be perceived as the consistent development and accumulation of expertise and knowledge among WA firms and industries, which contributes to looking for and securing sources of wealth creation and competitive advantage.

Several participants' views fit with the notions of sensing, seizing and transforming. For example, P11's views suggested the area where he was based had gone through various cycles of reconfiguration and transformation: "we have the most diverse economy in WA. There is agriculture, there is resource industry, there is tourism, there is aquaculture... when one sector declines, another sector takes its place." The aspect of knowledge acquisition and 
entrepreneurship were also manifested in P1's views: “...Before we were purely mining, oil and gas; now we want to be mining, oil, gas, agriculture... The plan B is to diversify our economy."

In agreement with Leonard-Barton (1992, in Teece et al. 1997) the findings illustrate innovative ways in which WA's business environment can build competitive advantage. For example, perceptions of maximising the extensive knowledge and expertise in mining, international education and research (P1, P3, P9, P13) or focusing on high-quality food production underscore the importance of configuration, reconfiguration, integration of knowledge, as well as developing and encouraging entrepreneurship. These different forms of strategic management contribute to the identification of specific ID initiatives that can complement the substantial economic contribution of the mining industry, and elevate the state's image on various industry fronts. The identified strategies and managerial resources, which support adaptation and renewal of economic focus among WA firms and industries, are partly aligned with Evers' (2011) discussion concerning the significance of product diversification to access new markets and add value.

Furthermore, the framework's theorisation that the continuous efforts of acquiring, configuring and integrating knowledge represent difficult to imitate resources was also revealed in the findings. First, the increasing focus of WA agricultural firms on high quality products allows them to target very demanding and lucrative overseas markets. Second, the state's tangible (physical) and intangible (skills, know-how) infrastructure in university education, or in other professional, upskilling areas (e.g., practical training) have earned the region an international reputation, which is difficult to replicate by potential competing regions or nations, and therefore represents competitive advantage. Moreover, based on some remarks (P1, P13), building partnerships, catering for emerging markets, and/or further positioning WA in existing and new industries could boost the state's chances to achieve sustained competitive advantage in several industries.

Third, the existing and future development of innovation and technology in various forms can also be a source of future competitive advantage. One illustration is P12's reference to film, music or digital communications, which appear to be well supported by expertise and skills. With higher demand for quality food products, food manufacturing and production could also become a source of competitive advantage for WA. This potential is further complemented by emerging industries, including WA's wine industry, or baby formula milk exports (P2): “...there is a big export... individuals bulk buying [baby formula] from normal shops. They're not buying it at wholesale prices... they're buying off the shelf of shops products."

As explained by P5, P7 and P13, best practice, implementation of technology and expertise can create significant commercial opportunities. These views are in agreement with a recent report (Department of Agriculture and Food, 2017), which highlights WA's ability to leverage its competitive strengths, supplying safer, traceable and high quality foods and beverages.

Fourth, the emerging tourism industry, where visitors can explore Australia's largest state and attractions, coupled with existing communications infrastructure, and geographic proximity to large tourist markets, also suggests potential for competitive advantage. The framework finally proposes that the above diversification alternatives will have direct impacts on the state in terms of sustained competitive advantage.

\section{Conclusions}

The present study makes various contributions to the academic literature. First, it proposes a theoretical framework grounded on the DCA to encourage a deeper reflection and understanding of the relationships between a region's available resources and its ID strategies 
to address a changing business environments. Second, the study makes a contribution to empirical knowledge, by gathering the perceptions of 15 trade and economic development experts representing WA's chambers of commerce, government agencies and town hall/shires. Their experiences and observations identified various strategies, which, in the case of tourism, international education and agriculture, further support and complement the evidence of government and industry reports (Government of Western Australia 2016, 2017; Tourism WA 2019; WAPETIA 2016).

More importantly, their comments underlined the strategic value of firm and industry managerial resources (Barney et al. 2001), which are manifested in existing capabilities, knowledge and assets. Also, in line with Teece (2012), the comments identified the alignment and realignment of resources (expertise in training/education, food production) to match demands and exploit business opportunities, thus, building competitive and sustained competitive advantage. These notions are also supported by views regarding the role of innovation and technology, notably, in creating new industries or business opportunities (e.g., creative industries; more energy efficient production methods), all of which will play a role on WA's future economic endeavours.

\subsection{Implications}

The findings have several key implications. Concerning practical implications, many participants' comments underscored the strategic value of managerial resources, both in ID initiatives, and in strengthening existing ones to maintain the state's competitive advantage internationally. As Teece et al. (1997) assert, competitive success partly occurs due to policies pursued, as well as efficiency and experience gained in earlier times. Experience and efficiency in the case of WA is clearly illustrated through the international demand for its products, not only in mining, but also in training/education and agricultural products. The findings also partly align with Wan (2005), who explains that the abundance of countries' resources allows firms "to command competitive advantages over most firms in other economies" (p. 168). In the case of the present study, such competitive advantages rest on firms' managerial resources (Barney et al. 2001) and DCs, allowing for ID, and consequently for exploiting distinctive advantages associated with sustained competitive advantage.

In this context, there are implications for policy makers. For instance, while WA continues to make strides, diversifying and developing alternative industries, it is crucial to develop ties with new or emerging consumer markets, while creating continuity and maintain consistency in product/service supply. These efforts will require the input, support, and involvement of policy makers, as well as members of local/regional governments, in working with producers and importers, as well as with other stakeholders in the supply chain (e.g., logistics/transportation companies, distributors, and researchers).

From a theoretical perspective, the proposed framework (Figure 1) helped ascertain various key relationships in concerning a region's ID. First, experts' knowledge and experience in trade and economic development indicated ways in which the WA's business/industry environment is changing. Second, and in line with Daft (1983) and Barney (1991), the framework helps explain some specific managerial resources (e.g., existing or new knowledge, organisational processes/attributes) and DCs in the context of ID. These managerial resources enable firms or their industry to undertake strategies, such as in the case of promoting international education, tourism, or food production, that result in improvements or in gaining in efficiency.

Third, the framework underscores the importance of strategic management in helping communicate and exploit potential opportunities, including through sensing, seizing, transforming, knowledge acquisition, or in encouraging entrepreneurship. Fourth, the framework elucidates that managerial resources and DCs are part of industries already 
playing an important role in WA's ID. These managerial resources and DCs are also identified in emerging industries that could contribute to WA's further diversification and to its competitive and/or sustained competitive advantage. The framework could be considered or incorporated in future research that examines regional economic development in changing business environments, particularly in providing a context for a critical discussion of the associations and interplay between managerial resources, DCs and ID initiatives.

\subsection{Limitations and future research}

The study has several limitations. For example, it only focuses on one Australian state, and on one nation, and therefore does not enable regional or country comparisons to be drawn from the themes under examination. Future research could extend the scope, and employ a comparative approach, which could provide insightful data for industry associations, chambers of commerce, or government trade agencies. For industry associations, new information could shed light on managerial resources, DCs, and strategies that are contributing to regional or country economic development. This information will inform those associations and firm entrepreneurs, especially in identifying and exploiting ID opportunities that emphasise the region's tangible and intangible resources.

Similarly, for chambers of commerce and government agencies, comparative regional or country data could pinpoint strengths that could encourage the building of strategic alliances and international trade. At the same time, the emerging data could inform potential investors, exporters or importers of products or services developed through ID efforts across regions and countries.

Future research could also further consider the DCA as a lens to examine the intersections within and between managerial resources, DCs and ID as tools to achieve competitive advantage. Similarly, adopting, testing and confirming/disconfirming this study's proposed framework will contribute to a more rigorous analysis of the interplay between those key elements. In turn, new theoretical insights will be proposed, leading to theory refinement and development.

\section{References}

Al-Marhubi, F. (2000) 'Export diversification and growth: an empirical Investigation', Applied Economics Letters, Vol. 7, No. 9, pp. 559-562.

Ambrosini, V. and Bowman, C. (2009) 'What are dynamic capabilities and are they a useful construct in strategic management?', International Journal of Management Reviews, Vol. 11, No. 1, pp. 29-49.

Arend, R.J. (2014) 'Entrepreneurship and dynamic capabilities: how firm age and size affect the 'capability enhancement-SME performance' relationship', Small Business Economics, Vol. 42 No. 1, pp. 33-57.

Arthur, W.B. (1994) 'Inductive reasoning and bounded rationality." The American Economic Review, Vol. 84, No. 2, pp. 406-411.

Augier, M., Teece, D.J. (2007) 'Dynamic capabilities and multinational enterprise: Penrosean insights and omissions', Management International Review, Vol. 47 No. 2, pp. 175-192.

Australian Government (2017a) China-Australia Free Trade Agreement [online] http://dfat.gov.au/trade/agreements/chafta/pages/australia-china-fta.aspx

Barney, J. (1991) 'Firm resources and sustained competitive advantage', Journal of Management, Vol. 17 No. 1, pp. 99-120.

Barney, J., Wright, M. and Ketchen Jr., D.J. (2001) 'The resource-based view of the firm: Ten years after 1991', Journal of Management, Vol. 27 No. 6, pp. 625-641.

Basha, K.N., Sweeney, J.C. and Soutar, G. (2015) 'Effects of country and delivery mode on 
perceived risk in international higher education', Journal of Marketing for Higher Education, Vol. 25 No. 2, pp. 171-203.

Bennett, D. (2010) 'Creative migration: a Western Australian case study of creative artists', Australian Geographer, Vol. 41 No. 1, pp. 117-128.

Brabazon, T. (2012) 'A wide open road? The strange story of creative industries in Western Australia', Creative Industries Journal Vol. 4 No. 2, pp. 171-193.

Chapman, R., Plummer, P. and Tonts, M. (2015) 'The resource boom and socio-economic well-being in Australian resource towns: a temporal and spatial analysis', Urban Geography, Vol. 36 No. 5, pp. 629-653.

Cheshire, L., Everingham, J.A. and Lawrence, G. (2014) 'Governing the impacts of mining and the impacts of mining governance: Challenges for rural and regional local governments in Australia', Journal of Rural Studies, Vol. 36, pp. 330-339.

Cieślik, J., Kaciak, E. and Welsh, D.H. (2012) 'The impact of geographic diversification on export performance of small and medium-sized enterprises (SMEs)', Journal of International Entrepreneurship, Vol. 10 No. 1, pp. 70-93.

Daft, R. (1983) Organization theory and design. New York: West.

Department of Agriculture and Food (2017) Western Australian agriculture and food: A global opportunity [online] https://www.agric.wa.gov.au/sites/gateway/files/Western\%20Australian\%20agricultur e\%20and\%20food\%3A\%20a\%20global\%20opportunity\%20-\%20PDF.pdf

DFAT (2017) Western Australia - Recent economic indicators [online] https://dfat.gov.au/trade/resources/Documents/wa.pdf

Døving, E. and Gooderham, P.N. (2008) 'Dynamic capabilities as antecedents of the scope of related diversification: the case of small firm accountancy practices' Strategic Management Journal, Vol. 29 No. 8, pp. 841-857.

DPIRD (2017) Western Australia's agriculture and food sector [online] https://www.agric.wa.gov.au/western-australias-agriculture-and-food-sector

Eisenhardt, K.M. and Martin, J.A. (2000) 'Dynamic capabilities: What are they?', Strategic Management Journal, Vol. 21, No. 10/11, pp. 1105-1121.

Eriksson, T., Nummela, N. and Saarenketo, S. (2014) 'Dynamic capability in a small global factory’, International Business Review, Vol. 23 No. 1, pp. 169-180.

Evers, N. (2011) 'International new ventures in "low tech" sectors: a dynamic capabilities perspective', Journal of Small Business and Enterprise Development, Vol. 18 No. 3, pp. 502-528.

Fusch, P.I. and Ness, L.R. (2015) 'Are we there yet? Data saturation in qualitative research', The Qualitative Report, Vol. 20 No. 9, pp. 1408-1416.

Gaur, A. and Delios, A. (2015) 'International diversification of emerging market firms: The role of ownership structure and group affiliation', Management International Review, Vol. 55 No. 2, pp. 235-253.

George, G.G. and Zahra, S.A.S. (2002) 'Culture and Its consequences for entrepreneurship', Entrepreneurship Theory and Practice, Vol. 26, No. 4, pp. 5-8.

Gioia, D.A. and Pitre, E. (1990) 'Multiparadigm perspectives on theory building', Academy of Management Review, Vol. 15 No. 4, pp. 584-602.

Goldstein, A., Pinaud, N., Reisen, N. and Chen, X. (2006) 'China and India: what's in it for Africa?', OECD Development Centre Studies, Paris, France.

Government of Western Australia (2016) China - Trade and investment with Western Australia [online]. http://www.jtsi.wa.gov.au/docs/default-source/default-documentlibrary/china.pdf?sfvrsn $=28$

Government of Western Australia (2017) Western Australia - Economic profile [online] 
http://www.jtsi.wa.gov.au/docs/default-source/default-document-library/waeconomic-profile-09179f550fa57ba2628e86e4ff0000981137.pdf?sfvrsn=4

Guest, G., Bunce, A. and Johnson, L. (2006) 'How many interviews are enough? An experiment with data saturation and variability', Field Methods, Vol. 18 No. 1, pp. 59-82.

Helfat, C.E. and Peteraf, M.A. (2009) 'Understanding dynamic capabilities: progress along a developmental path', Strategic Organization, Vol. 7 No. 1, pp. 91-102.

Hitt, M.A., Hoskisson, R.E. and Kim, H. (1997) 'International diversification: Effects on innovation and firm performance in product-diversified firms', Academy of Management Journal, Vol. 40 No. 4, pp. 767-798.

Hood, J. (2007) 'Orthodoxy versus power: The defining traits of grounded theory', In A. Bryant and K. Charmaz (eds.), Handbook of grounded theory (pp. 151-164). London, UK: Sage Publications Inc.

Hsieh, H.F. and Shannon, S.E. (2005) 'Three approaches to qualitative content analysis', Qualitative Health Research, Vol. 15 No. 9, Vol. 1277-1288.

Hyde, K.F. (2000) 'Recognising deductive processes in qualitative research', Qualitative Market Research: An International Journal, Vol. 3 No. 2, pp. 82-90.

Kamien, M.I. and Schwartz, N.L. (1975) 'Market structure and innovation: a survey', Journal of Economic Literature, Vol. 13 No. 1, pp. 1-37.

La Rocca, M., La Rocca, T., Gerace, D. and Smark, C. (2009) 'Effect of diversification on capital structure', Accounting and Finance, Vol. 49 No. 4, pp. 799-826.

Lawrie, M., Tonts, M. and Plummer, P. (2011) 'Boomtowns, resource dependence and socioeconomic well-being', Australian Geographer, Vol. 42 No. 2, pp. 139-164.

Leih, S. and Teece, D. (2016) 'Campus leadership and the entrepreneurial university: A dynamic capabilities perspective', The Academy of Management Perspectives, Vol. 30 No. 2, pp. 182-210.

Lenzen, M., Geschke, A., Malik, A., Fry, J., Lane, J., Wiedmann, T., Kenway, S., Hoang K, and Cadogan-Cowper A (2017) 'New multi-regional input-output databases for Australia-enabling timely and flexible regional analysis', Economic Systems Research, Vol. 29 No. 2, pp. 275-295.

Leonard-Barton, D. (1992) 'Core capabilities and core rigidities: A paradox in managing new product development', Strategic Management Journal, Vol. 13, No. 1, pp. 111-125.

Liu, H.Y. and Hsu, C.W. (2011) 'Antecedents and consequences of corporate diversification: A dynamic capabilities perspective', Management Decision, Vol. 49, No. 9, pp. 15101534.

Maritan, C.A. (2007) Dynamic capabilities and organizational processes. In C. Helfat, S. Finkelstein, W. Mitchell, M.A. Peteraf, H. Singh, D.J. Teece, and S.G. Winter (eds.), Dynamic capabilities: Understanding strategic change in organizations (pp. 30-46). , Maiden, MA: Blackwell.

Mayer, M.C., Stadler, C. and Hautz, J. (2015) 'The relationship between product and international diversification: The role of experience', Strategic Management Journal, Vol. 36 No. 10, pp. 1458-1468.

O'Reilly, M. and Parker, N. (2013) 'Unsatisfactory Saturation': a critical exploration of the notion of saturated sample sizes in qualitative research', Qualitative Research, Vol. 13 No. 2, pp. 190-197.

Palinkas, L.A., Horwitz, S.M., Green, C.A., Wisdom, J.P., Duan, N. and Hoagwood, K. (2015) 'Purposeful sampling for qualitative data collection and analysis in mixed method implementation research', Administration and Policy in Mental Health and Mental Health Services Research, Vol. 42 No. 5, pp. 533-544.

Patton, M.Q. (2002) Qualitative research and evaluation methods ( $3^{\text {rd }}$ ed.). Thousand Oaks, 
CA: Sage Publications.

Perry, M. and Rowe, J.E. (2015) 'Fly-in, fly-out, drive-in, drive-out: The Australian mining boom and its impacts on the local economy', Local Economy, Vol. 30 No. 1, pp. 139148.

Petkova, V., Lockie, S., Rolfe, J. and Ivanova, G. (2009) 'Mining developments and social impacts on communities: Bowen Basin case studies', Rural Society, Vol. 19 No. 3, 211-228.

Pham, T., Jago, L., Spurr, R. and Marshall, J. (2015) 'The Dutch Disease effects on tourismThe case of Australia', Tourism Management, Vol. 46, pp. 610-622.

Pforr, C., Pechlaner, H., Volgger, M. and Thompson, G. (2014) 'Overcoming the limits to change and adapting to future challenges: Governing the transformation of destination networks in Western Australia', Journal of Travel Research, Vol. 53 No. 6, pp. 760777.

Rodger, K., Taplin, R.H. and Moore, S.A. (2015) 'Using a randomised experiment to test the causal effect of service quality on visitor satisfaction and loyalty in a remote national park', Tourism Management, Vol. 50, pp. 172-183.

Rutherford, J., Kobryn, H. and Newsome, D. (2015) 'A case study in the evaluation of geotourism potential through geographic information systems: application in a geology-rich island tourism hotspot', Current Issues in Tourism, Vol. 18 No. 3, pp. 267-285.

Teece, D.J. (2014) 'The foundations of enterprise performance: Dynamic and ordinary capabilities in an (economic) theory of firms', The Academy of Management Perspectives, Vol. 28, No. 4, pp. 328-352.

Teece, D.J. (2012) 'Dynamic capabilities: Routines versus entrepreneurial action', Journal of Management Studies, Vol. 49 No. 8, pp. 1395-1401.

Teece, D.J., Pisano, G. and Shuen, A. (1997) 'Dynamic capabilities and strategic management', Strategic Management Journal, Vol. 18 No. 7, pp. 509-533.

Thomas, D.R. (2006) 'A general inductive approach for analyzing qualitative evaluation data', American Journal of Evaluation, Vol. 27 No. 2, pp. 237-246.

Thornhill, J. (2017) Australia's mining bust town reawakens. Bloomberg online: https://www.bloomberg.com/news/articles/2017-05-23/aussie-mining-bust-townreawakens-as-buyers-decide-slump-is-over

Tonts, M., Martinus, K, and Plummer, P. (2013) 'Regional development, redistribution and the extraction of mineral resources: the Western Australian Goldfields as a resource bank', Applied Geography, Vol. 45, pp. 365-374.

Tonts, M., Selwood, J. (2003) 'Niche markets, regional diversification and the reinvention of Western Australia's sandalwood industry', Tijdschrift voor Economische en Sociale Geografie, Vol. 94 No. 5, pp. 564-575.

Tourism WA (2019) International visitation - Fast facts - Year ending December 2018 [online]: https://www.tourism.wa.gov.au/Publications\%20Library/Research\%20and\%20reports 12018/IVS\%20Fast\%20Facts\%20YE\%20Dec\%2018.pdf

Trendle, B. and Shorney, G. (2003) 'The effect of industrial diversification on regional economic performance', Australasian Journal of Regional Studies, Vol. 9 No. 3, pp. 355-369.

Villar, C., Alegre, J. and Pla-Barber, J. (2014) 'Exploring the role of knowledge management practices on exports: A dynamic capabilities view', International Business Review, Vol. 23 No. 1, pp. 38-44.

Wahlquist, C. (2017) 'They've lost the lot': how the Australian mining boom blew up in property owners' faces. The Guardian online: 
https://www.theguardian.com/australia-news/2017/may/12/theyve-lost-the-lot-howthe-australian-mining-boom-blew-up-in-property-owners-faces

Wacker, J.G. (1998) 'A definition of theory: research guidelines for different theory-building research methods in operations management', Journal of Operations Management, Vol. 16 No. 4, pp. 361-385.

Walker, J.L. (2012) 'Research column. The use of saturation in qualitative research', Canadian Journal of Cardiovascular Nursing, Vol. 22 No. 2, pp. 37-41.

Wan, W.P. (2005) 'Country resource environments, firm capabilities, and corporate diversification strategies', Journal of Management Studies, Vol. 42 No. 1, pp. 161182.

WAPETIA (2016) Western Australia's international education sector [online]: http://bcec.edu.au/assets/western-australias-international-education-sector.pdf

Weerawardena, J., Mort, G.S., Liesch, P.W. and Knight, G. (2007) 'Conceptualizing accelerated internationalization in the born global firm: A dynamic capabilities perspective', Journal of World Business, Vol. 42 No. 3, pp. 294-306.

Weiss, D. and Greenwood, J. (2015) Mining Surplus: Modeling James A. Schmitz's link between competition and productivity. Discussion Paper No. 9-15. The Pinhas Sapir Center for Development, Tel-Aviv University, Tel-Aviv, Israel.

Welsh, E. (2002) 'Dealing with data: Using NVivo in the qualitative data analysis process', Forum: Qualitative Social Research, Vol. 3, No. 2. 
Table 1 - Participating entities

\begin{tabular}{|c|c|c|c|c|}
\hline P* & Industry/organisation & Role & $\begin{array}{c}\text { Experience } \\
* *\end{array}$ & Gender \\
\hline P1 & Chamber of commerce & Director & 7 & Male \\
\hline P2 & Chamber of commerce & Director/CEO & 8 & Female \\
\hline P3 & Chamber of commerce & Director 1 & 6 & Female \\
\hline P4 & Chamber of commerce & Director 2 & 5 & Female \\
\hline P5 & Chamber of commerce & Director & 11 & Male \\
\hline P6 & Chamber of commerce & Director/CEO & 15 & Female \\
\hline P7 & Shire/Town & CEO & 3 & Male \\
\hline P8 & Shire/Town & CEO & 3 & Male \\
\hline P9 & Shire/Town & $\begin{array}{c}\text { Coordinator, } \\
\text { economic } \\
\text { development }\end{array}$ & 4 & Male \\
\hline P10 & Shire/Town & $\begin{array}{c}\text { Coordinator, } \\
\text { economic } \\
\text { development }\end{array}$ & 5 & Male \\
\hline P11 & Shire/Town & $\begin{array}{c}\text { Coordinator, } \\
\text { economic } \\
\text { development }\end{array}$ & 3 & Male \\
\hline P12 & Government (foreign trade) & Trade advisor & 5 & Male \\
\hline P13 & Government (foreign trade) & Director & 2 & Male \\
\hline P14 & Government (regional) & Director & 7 & Male \\
\hline P15 & Port Operations/Trade & Coordinator & 6 & Female \\
\hline
\end{tabular}

* Represents 'participant'. ** Experience in management/coordination in years. 
Table 2: Content analysis - Perceived ways to maximise WA's economic diversification

\begin{tabular}{|l|r|r|}
\hline Main responses - Themes * & n & \multicolumn{1}{c|}{$\%$} \\
\hline Tourism, tourism industry & 11 & 73.3 \\
\hline International education & 10 & 66.7 \\
\hline Innovation and technology & 9 & 60.0 \\
\hline Agriculture & 8 & 53.3 \\
\hline Wine industry & 4 & 26.7 \\
\hline Exploiting the positive image of WA / Australia (e.g., for products, infrastructure) & 4 & 26.7 \\
\hline Exporting other foods (meat, baby formula) & 4 & 26.7 \\
\hline Exploiting free trade agreements (e.g., with China) & 3 & 20.0 \\
\hline Exploiting the same/similar time zone as that of large neighbouring markets & 2 & 13.3 \\
\hline Infrastructure development (e.g., port facilities) & 1 & 6.7 \\
\hline Adding-value to the state's production (e.g., food, mining) & 1 & 6.7 \\
\hline
\end{tabular}

* More than one response identifying one or more themes was possible

\section{Content analysis - Nodes clustered by word similarity}

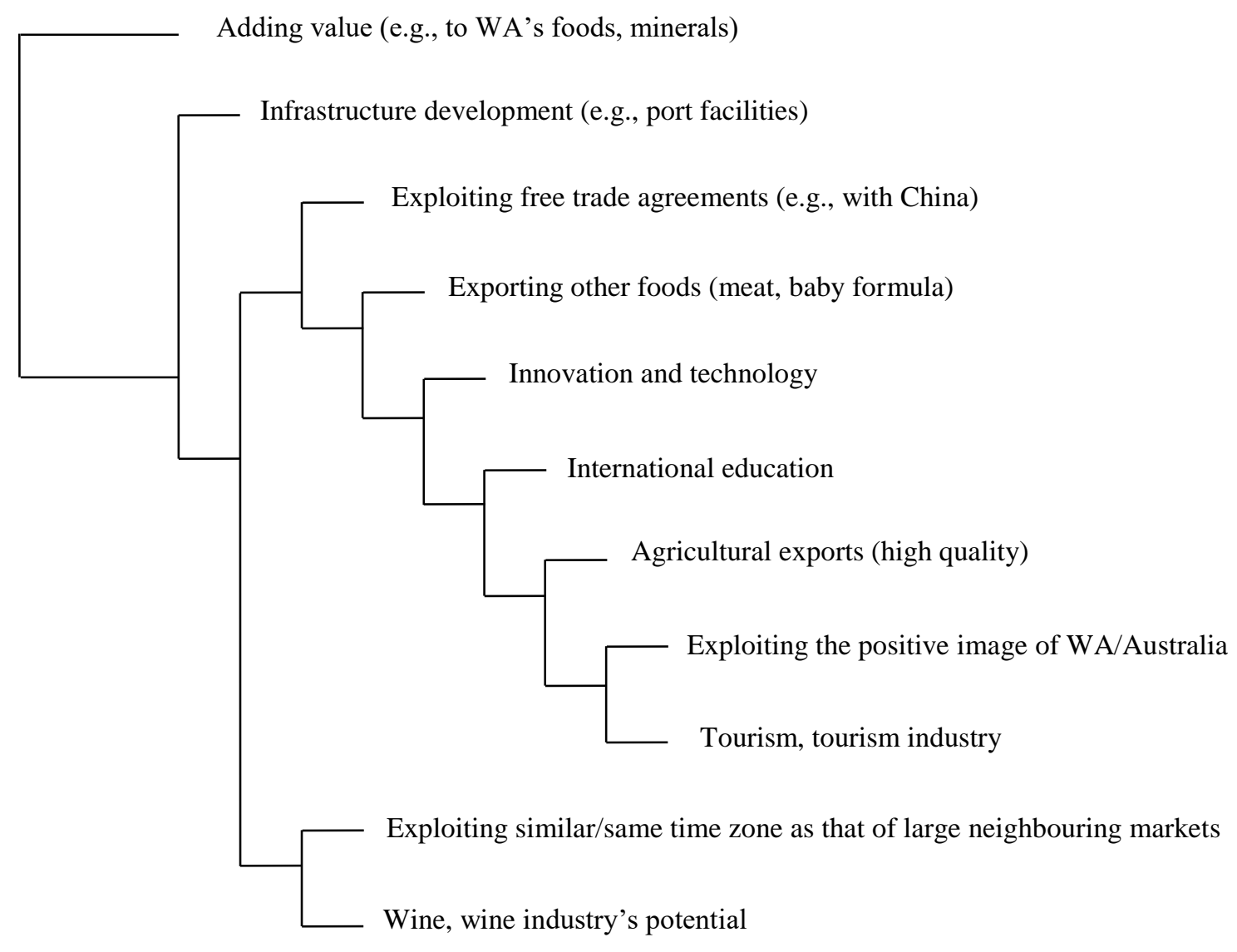


Figure 1: Dynamic capabilities and diversification in the context of a region Sources: Augier and Teece, 2008; Barney, 1991; George and Zahra, 2002; Teece et al., 1997; Teece, 2012, 2014; Weerawardena et al., 2007

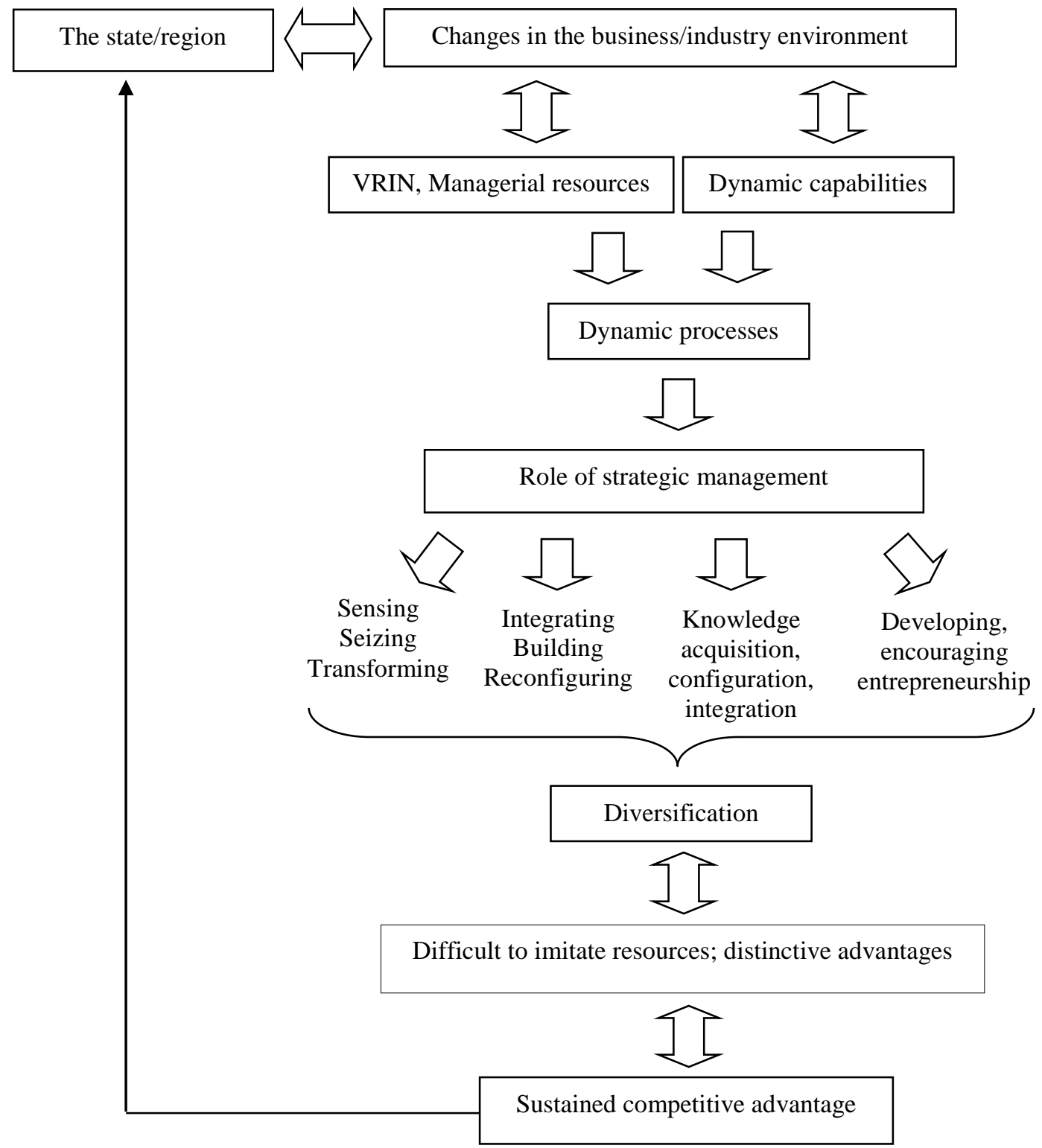

